\title{
PEMBENTUKAN KARAKTER ANAK MELALUI KOMUNIKASI INTERPERSONAL DAN KETELADANAN ORANGTUA PADA KELAS VI SDI AL-ACHFAS DWI MATRA JAKARTA
}

\author{
HUNAINAH \\ Dosen Program Studi Pendidikan Agama Islam Fakultas Agama Islam \\ Universitas Muhammadiyah Palangkaraya
}

\begin{abstract}
The aim of the research is to find out children's character development through interpersonal communication and parents' role model in Islamic Elementary School Al-Achfas Dwi Matra South Jakarta. This research is conducted by using Descriptive method. The data is collected through observation, interview, and documentation, and then it is analyzed descriptively by several steps such as data reduction, data presentation and deduction. Parents with good interpersonal communication are the source of children's physical and spiritual health. Therefore, a child who is educated communicatively with good role model will grow as a mature human being who is physically and spiritually healthy. A good role model is an effective method to teach moral values to children due to their character as imitators. The result of this research shows that parents in Islamic Elementary School Al-Achfas Dwi Matra Jakarta are able to provide interpersonal communication and good role model in children's character development.
\end{abstract}

Keywords: interpersonal communication, role model

\section{ABSTRAK}

Tujuan dari penelitian ini adalah untuk mengetahui pembentukan karakter anak melalui komunikasi interpersonal dan keteladanan orangtua di Sekolah Dasar Islam Al-Achfas DwiMatra Jakarta Selatan. Metode deskriptif digunakan dalam penelitian ini. Pengumpulan data dilakukan melalui obeservasi, wawancara, dan dokumentasi, kemudian dianalisa secara deskriptif melalui tahapan yaitu reduksi data, penyajian data, dan pengambilan kesimpulan. Orang tua dengan komunikasi interpersonal yang baik adalah sumber kesehatan fisik dan spiritual anak. Oleh karena itu, seorang anak dididik dengan penuh komunikasi dan keteladanan yang baik akan tumbuh menjadi manusia dewasa yang sehat jasmani dan rohani. Keteladanan yang baik adalah metode yang efektif untuk mengajarkan nilai-nilai moral kepada anak karena sifatnya sebagai peniru. Hasil penelitian ini menunjukkan bahwa orang tua dari murid di Sekolah Dasar Islam Al-Achfas DwiMatra Jakarta mampu menyediakan komunikasi interpersonal dan keteladanan yang baik pada pembentukan karakter anak.

Kata kunci : komunikasi interpersonal, keteladanan

\section{PENDAHULUAN}

Anak merupakan amanah dari Allah Swt yang harus dijaga dan dibina dan dibimbing dengan hal baik. Cara memeliharanya adalah dengan upaya pendidikan dan mengajarinya dengan karakter yang baik. Oleh karena itu orangtualah memegang kunci sehingga anak tumbuh dengan jiwa Islami sebagaimana sabda Rasulullah Saw.

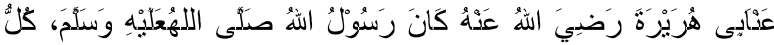

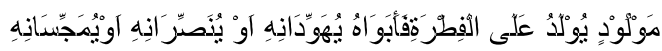

"Dari Abu Hurairah ra. sesungguhnya Rasullullah Saw bersabda, tiap anak dilahirkan dalam keadaan suci. Maka kedua orangtuanyalah yang menjadikannya seorang Yahudi, Nasrani, atau Majusi" (HR.Muslim) (al-Bukhari;1987,I,465). 
Bersandar dari hadits ini setiap anak dilahirkan dalah keadaan suci bersih dan tidak ternoda. Hal ini menunjukkan bahwa anak lahir dalam keadaan tidak berdaya dan belum dapat berbuat apa-apa, sehingga masih sangat tergantung kepada kedua orangtua dan lingkungannya. Maka, peran kedua orangtua sangat berpengaruh terhadap perkembangan pembentukan karakter anak. Kedua orangtua harus siap menjadi pendidik dan pembimbing bagi anak-anaknya. Orangtua tidak hanya cukup memberikan atau memenuhi kebutuhan jasmani anak berupa sandang, pangan, dan papan. Akan tetapi, orangtua harus memberikan atau memenuhi kebutuhan rohani anak yakni dengan pengetahuan agama maupun pengetahuan umum agar terbentuk kepribadian anak yang berlandaskan keimanan dan ketakwaan.

Melihat kasus di Indonesia terjadinya beberapa dekadensi moral yaitu krisis akhlak. Akar praktik kolusi-nepotisme adalah kuatnya tradisi anak penguasa yang selalu mendapat kemudahan berusaha karena jaringan kekuasaan yang dibangun oleh orangtua mereka. (Mansyur Semma: 2008, 25). Seiring dengan kemajuan ilmu pengetahuan dan teknologi dewasa ini, banyak orangtua yang mengabaikan pendidikan karakter bagi anak-anaknya. Tuntutan zaman menyebabkan para orangtua cenderung memberi perhatian lebih pada pendidikan fisik dan intelijen saja (Munif Chatib: 2009, 5). Masalah generasi muda saat ini sangat mencemaskan, karena akan membuat sebuah bangsa tenggelam sedikit demi sedikit. Karakter dan kualitas anak bangsa Indonesia sangat memprihatinkan dengan adanya masalah kemerosotan moral, di antaranya:

\section{Meningkatnya Kekerasan di Kalangan Remaja}

Data kepolisian Polda Metro Jaya tahun 2000 menunjukkan bahwa tindakan kekerasan yang dilakukan para pelajar setiap tahun mengalami peningkatan. Dari data tersebut diperoleh informasi bahwa banyak kasus kekerasan pelajar terutama dilakukan oleh pelajar STM. (Reni Akbar Hawadi: 2004,167).

\section{Mudah dan Ringannya Penggunaan Bahasa dan Kata-kata Kasar}

Penelitian yang dilakukan Yayasan Kesejahteraan Anak Indonesia (YLKI) persentase acara televisi materinya sangat menghawatirkan bagi perkembangan anak (Deddy Mulyana dan Idi Subandy Ibrahim: 1997, 214).

\section{Hilangnya Rasa Empati Anak Kepada Orang Lain}

Hilangnnya rasa empati ini bersama pengaruh lingkungan, telah berhasil menjadi pemicu semakin rendahnya rasa hormat kepada orangtua dan gurulni juga dikarenakan banyak anak kehilangan figur sentral dalam kehidupannya. Banyak anak yang lebih cenderung untuk menjadikan tontonan sebagai model.

\section{Ketidakjujuran yang Membudaya}

Terbongkarnya kasus contek massal siswa kelas VI SD Negeri Gadel II, Kecamatan Tandes, Surabaya, Jawa Timur, membuktikan harga kejujuran semakin mahal. (Doni Koesoema, 2010: 22). 
Akar dari masalah krisis karakter ini cukup banyak masalahnya, yang terpenting di antaranya adalah karena longgarnya pegangan terhadap agama;pembinaan moral yang dilakukan oleh orangtua, sekolah, dan masyarakat sudah kurang efektif; kebiasaan orangtua memberikan keteladanan yang baik kurang banyak dilakukan; derasnya arus budaya materialistik, hedonistik dan sekularistik.(Abuddin Nata, 2007: 218)

Masalah komunikasi juga bisa berakar dari hilangnya rasa hormat antara anak dan orangtua, baik dirinya sebagai anak atau sebagai orangtua sama-sama tidak mau saling mendengar, keduaduanya ingin jadi penguasa dalam suatu komunikasi inilah yang bisa menyebabkan hilangnya rasa hormat antar anak dan orangtua, (Jenny Gichara, 2006: 9). Dalam berkomunikasi, Islam sangat menekankan untuk memulai komunikasi dengan panggilan yang menyenangkan sekalipun pesan yang disampaikan dalam komunikasi merupakan teguran dan peringatan. Allah telah mencontohkan hal tersebut ketika sedang menegur kesalahan Rasulullah. Allah tetap memanggil beliau dengan sebutan "wahai Nabi".

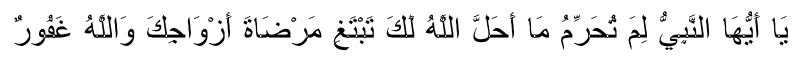

"Wahai Nabi, mengapa kamu mengharamkan apa yang Allah menghalalkannya bagimu; kamu mencari kesenangan hati istri-istrimu? Dan Allah Maha pengampun lagi Maha penyayang" (QS. alTahrim [66]: 1)

Dari ayat ini sangat jelas bahwa komunikasi yang dicontohkan oleh Allah adalah untuk tidak menjatuhkan lawan bicara tetapi untuk memberi arahan yang baik tanpa mengganggu perasaan lawan bicara.Dengan demikian maka dengan penelitian ini mencoba meliha bagaimana pola komunikasi interpersonal yang diiring dengan keteladanan orangtua menjadi salah satu faktor dalam pembentukan karakter anak.

\section{METODOLOGI}

Penelitian ini menggunakan metode kualitatif case study research (CSR)atau penelitian studi kasus deskriptif, karena peneliti sebagai alat untuk melakukan penjelajahan, sehingga masalah akan dapat dijelajah secara jelas dan mendalam (Sugiyono, 2006: 23). Lokasi penelitian dalam penulisan ini adalah SDI AIAchfas Dwi Matra. Jl. Jaha No. 30 B Cilandak Timur Pasar Minggu Jakarta Selatan.

Peneliti sendiri menjadi instrumen (human instrument) yang melakukan perencanaan, pelaksana pengumpulan data, analisis, penafsir data, dan pelapor hasil data. Kemudian, dikembangkan melalui observasi dan wawacara yang dilakukan oleh peneliti ke lapangan. Subyek penelitian adalah orangtua dari murid kelas VI SDI Al-Achfas Dwi Matra tahun ajaran 2012-2013 sedangkan informan dalam penelitian ini adalah anak yang menjadi siswa/siswi terkait di sekolah di atas. Adapun teknik pengumpulan data yang digunakan dalam penelitian ini adalahobservasi, wawancara, dan dokumentasi.Proses analisis penelitian ini sejalan dengan yang dikatakan Mathew B. Miles dan A. Michael Huberman yakni menggunakan teknik analisis deskriptif (Lexy $\mathrm{J}$ Moleong, 2010: 397) yang disederhanakan menjadi tiga tahap yaitu: reduksi data, penyajian data dan penarikan kesimpulan. 


\section{PEMBAHASAN}

\section{Pendidikan Karakter}

Dengan adanya faktor pembentuk karakter, baik secara nature dan nurture, membentuk karakter harus dimulai dari keluarga. Karena, keluarga adalah lingkungan yang pertama dan utama dikenal oleh anak. Jadi, dalam lingkungan keluargalah watak dan kepribadian anak akan dibentuk yang sekaligus akan mempengaruhi perkembangannya di masa depan.(AgusSujanto, 2006: 3) Ratna Megawangi bersama dengan timyang tergabung dalam Indonesia Heritage Foundation (IHF), menyusun 9 pilar karakter yang harus diajarkan kepada anak-anak.(Ratna Megawangi, 2004: 100) Sembilan pilar karakter tersebut adalah sebagai berikut:

1. Cinta Tuhan dan segenap ciptaan-Nya (love Allah, trust, reverence, loyalty)

2. Kemandirian dan tanggung jawab (responsibility, excellence, self reliance, discipline, orderliness)

3. Kejujuran/amanah, bijaksana (trustworthinnes, reliability, honesty)

4. Hormat dan santun (respect, courtessy, obedience)

5. Dermawan, suka menolong, dan gotong royong (love compassion, caring, empathy, generousity, moderation, cooperation)

6. Percaya diri, kreatif, dan pekerja keras (confidence, assertiveness, creativity, resourcefullness, courage, determination and enthusiasm)

7. Kepemimpinan dan keadilan (justice, fairness, mercy, leadership)

8. Baik dan rendah hati (kindness, frienliness, humility, modesty)
9. Toleransi dan kedamaian dan kesatuan (tolerance, flexibility, peacefullness, unity)

Kesembilan pilar karakter yang telah dikembangkan oleh IHF di atas, sejalan dengan nilai-nilai yang ditanamkan dalam konsep Pendidikan Kecakapan Hidup (life skill) melalui pendidikan berbasis luas (Broad Based Education) yang diluncurkan Diknas pada tahun 2002. Adapun aspek general life skill yang berkaitan dengan 9 pilar karakter tersebut adalah sebagai berikut:

a. Kesadaran diri (self awareness), yang meliputi:

1. Keimanan sebagai makhluk Tuhan Yang Maha Esa (pilar 1)

2. Pengembangan karakter: cinta kebenaran (pilar 1), tanggung jawab dan disiplin (pilar 2), saling menghargai (pilar 4), kejujuran (pilar 3) dan membantu (pilar 5)

3. Belajar memelihara lingkungan (pilar 5)

b. Kesadaran akan potensi diri

1. Belajar menolong diri sendiri (pilar 2)

2. Belajar menumbuhkan kepercayaan diri (pilar 6)

c. Kecakapan sosial (social skill)

1. Empati (pilar 5)

2. Bekerja sama (pilar 5)

Dalam konsep Islam, karakter tidak sekali terbentuk, lalu tertutup, tetapi terbuka bagi semua bentuk perbaikan, pengembangan, dan penyempurnaan, sebab sumber karakter perolehan ada dan bersifat tetap. Karenanya orang yang membawa sifat kasar bisa memperoleh sifat lembut, setelah melalui mekanisme latihan. (M. Anis Matta, 2002: 10) Namun, sumber karakter itu hanya bisa bekerja efektif jika kesiapan dasar seseorang berpadu 
dengan kemauan kuat untuk berubah dan berkembang, dan latihan yang sistematis.

Bagi Muslim, nilai-nilai Islam diyakini sebagai pembentuk karakter dan sekaligus bisa menjadi dasar nilai bagi masyarakat majemuk. (Zakiyuddin Baidhawy, 2007: 74) Namun, dalam soal pendidikan karakter, berbagai agama bisa bertemu. Al-Ghazali memiliki pandangan unik. la menyatakan bahwa sumber pembentukan karakter yang baik itu dibangun melalui internalisasi Asma' al-Husna dalam perilaku seseorang. (Al-Ghazali, tt: 104) Maka sebagai pendidik dan pengajar, orangtua harus tampil sebagai teladan yang baik. Manusia dipahami sebagai makhluk yang memiliki potensi fitrah dimana terdapat daya-daya yang dapat memunculkan sebuah sikap dan perilaku yang tidak lepas dari stimulus dari luar. Artinya, Islam memandang, karakter manusia tidak murni karena faktor potensi, tetapi juga faktor lingkungan yang mempengaruhinya.

\section{Komunikasi Interpersonal dan Keteladanan}

Komunikasi interpersonal adalah komunikasi antara dua orang secara tatap muka, yang memungkinkan setiap pesertanya menangkap reaksi orang lain secara langsung, baik secara verbal atau nonverbal (Dedy Mulyana, 2000: 75) Efektivitas komunikasi interpersonal dimulai dengan lima kualitas umum yang dipertimbangkan; yaitu keterbukaan (openness), empati (empathy), sikap mendukung (supportiveness), sikap positif (positiveness), dan kesetaraan (equality) (Joseph ADevito, 1989: 259). Dengan adanya lima kualitas umum diharapkan upaya mengubah sikap, pendapat atau perilaku seseorang bisa dilakukan dengan baik. Orangtua seyogyanya bisa menjadi pendengar yang baik bagi anak-anak mereka, dapat menyampaikan nilai-nilai positif yang akan menjadi landasan hidup. Hal ini dijelaskan dalam firman Allah Swt,

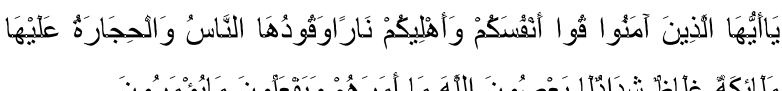
"Hai orang-orang yang beriman, peliharalah dirimu dan keluargamu dari api neraka yang bahan bakarnya adalah manusia dan batu; penjaganya malaikat-malaikat yang kasar, keras, dan tidak mendurhakai Allah terhadap apa yang diperintahkan-Nya kepada mereka dan selalu mengerjakan apa yang diperintahkan". (QS alTahrim [66]: 6)

Hal yang terkadang terlupa dari benak orangtua adalah perbedaan antara berbicara kepada anak dengan berbicara dengan anak. Yang dimaksud komunikasi dua arah ini adalah jika berbicara kepada anak, maka ada unsur instruksi, sedangkan jika berbicara dengan anak, yang terasa adalah suasana diskusi (A.Supratiknya, 1995: 38). Akibatnya, dijumpai kasus yang menimpa anak akibat dari pola komunikasi yang salah yang digunakan oleh orangtua (A.Supratiknya, 1995: 56). Di antara kasus itu adalah sebagian orangtua yang berbicara kepada anak, lebih sering menyampaikan pesan negatif terhadap anaknya ketimbang positif, bahkan hampir tak pernah. Seperti dengan mengatakan "mana mungkin kamu bisa", "sudahlah kamu tidak usaha bermimpi", "kamu itu tidak bisa diandalkan", "kamu itu selalu salah, apa sih yang mampu kamu kerjakan dengan baik?" Akibatnya anak merasa tidak didukung oleh orangtuanya. Ada beberapa langkah yang bisa dilakukan agar komunikasi 
interpersonal antara anak dan orangtua menjadi lebih efektif : munculkan Rasa Menerima; membuka Pintu; mendengar Aktif (Thomas Gordon, 1989: 26).

Dalam perspektif Islam, komunikasi merupakan bagian tak terpisahkan. Komunikasi yang berakhlak al-karimah berarti komunikasi yang bersumber kepada al-Quran dan hadist (Ahmad Ghulusy, 1987: 9). Sebagaimana firman Allah Swt,

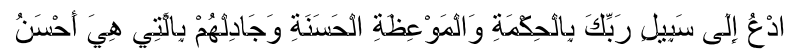
"Serulah (manusia) kepada jalan Tuhan-mu dengan hikmah dan pelajaran yang baik dan bantahlah mereka dengan cara yang baik."(QS an-Nahl [16]: 125)

Komunikasi dalam Islam dinilai penting, karena adanya kewajiban berda'wah kepada setiap orang-orang yang beriman sehingga nilainilai al-Qur'an dan haditsnya harus selalu dikomunikasikan kepada orang lain, khususnya dalam ruang lingkup keluarga, guna menghindari siksaan api neraka. Dalam Islam komunikasi harus dilandasi dengan cinta dan kasih sayang. Tidak ada alasan bagi seseorang untuk keluar dari etika-etika yang telah digarisbawahi oleh risalah Islam (Abdul Muis, 2001: 72). Hal tersebut telah dicontohkan langsung oleh Allah dalam alQur'an. Karenanya didapati bahwa setiap surah dalam al-Qur'an selalu diawali dengan Bismillahi Rahmaani Rahiim (Dengan nama Allah Yang Maha Pengasih Lagi Maha Penyayang). Terlebih lagi, kecenderungan mencontoh sangat besar peranannya pada anak-anak, sehingga perkembangan anak dalam proses membangun kepribadian akan terbantu dengan modeling (AgusSujanto, 2006: 6).

\section{Membentuk Karakter Anak Melalui Komunikasi Interpersonal Dan Keteladanan Orangtua}

Pembahasan pembentukan karakter anak yang terdiri dari sembilan pilar ini telah didengungkan dan disosialisasikan oleh Kementrian Pendidikan Nasional dari hasil Sarasehan Nasional Pendidikan Bangsa yang dilaksanakan di Jakarta tanggal 14 Januari 2010 (Muchlas Samani dan Hariyanto, 2012: 95). Karena itu, seyogyanya pendidikan karakter perlu diberikan sedini mungkin, dari pendidik terdekat, yakni orangtua. Sembilan pilar karakter tadi hampir serupa dengan pendidikan karakter di negara barat seperti Amerika Serikat, Kanada, Inggris yang amat dipengaruhi oleh konsep pendidikan Thomas Lickona. Menurut Lickona dalam pendidikan karakter antar lain meliputi nilai amanah, rasa hormat, bertanggung jawab, berlaku adil, kepedulian, kejujuran, keberanian, kerajinan, berintegritas dan kewarganegaraan (Doni Koesoema Albertus, 2010: 89). Dengan demikian nilai-nilai karakter yang banyak berkembang di negara maju sebenarnya sudah lama hadir di bumi Indonesia baik dari tradisi budaya dan agama (Muchlas Samani dan Hariyanto, 2012: 98).

Dalam pandangan Islam karakter hadir di semua sisi kehidupan tidak hanya sempilan pilar yang telah didengungkan tetapi karakter dalam Islam berasal dari dua sumber utama, yaitu alQur'an dan Sunnah (termasuk perbuatan, perkataan dan perintah tidak langsung, serta kehendak Nabi), dan oleh sebab itu, sumber karakter merupakan wahyu llahi. Metode pendidikan dalam al-Qur'an didasarkan pada penyelesaian problematika yang ada, mengomentari kejadian-kejadian yang sedang 
terjadi dan menetapkan masalah-masalah yang menjadi polemik, dimana al-Qur`an itu diturunkan mengikuti kehidupan masyarakat Islam pertama sehingga pengaruhnya benar-benar mewarnai dan tidak dapat dihapus dalam hati.

Begitu pula halnya dengan Sunnah Nabi Muhammad Saw, dimana ketika ada kejadian yang didengar atau dilihat Rasulullah maka muncullah komentar beliau, penetapan atau pengingkaran atas kejadian tersebut sehingga pendidikan yang langsung dipraktikkan dapat meninggalkan bekas yang kuat pada kepribadian para sahabatnya. Hal inilah yang juga merupakan konsep pendidikan karaker dalam Islam.

Sehubungan dengan Karakter Islami, Sahilun A. Nasir (Sahilun A. Nasir dan Hafi Anshari, 1989: 80) menyebutkan bahwa karakter Islami berkisar pada:

1. Tujuan hidup setiap Muslim, ialah menghambakan dirinya kepada Allah untuk mencapai keridhaan-Nya, hidup sejahtera lahir dan batin, dalam kehidupan masa kini dan masa yang akan datang.

2. Dengan keyakinannya terhadap kebenaran wahyu Allah dan Sunnah Rasul-Nya, membawa konsekwensi logis, sebagai standar dan pedoman utama bagi setiap moral muslim. la memberi sangsi terhadap moral dalam kecintaan dan kekuatannya kepada Allah Swt. Tanpa perasaan adanya tekanan-tekanan dari luar.

3. Keyakinannya akan hari kemudian/ pembalasan, mendorong manusia berbuat baik dan berusaha menjadi manusia sebaik mungkin, dengan segala pengabdiannya kepada Allah.
4. Karakter manusia selalu bersentuhan dengan ajaran jiwa Islam, berasaskan dari al-Qur'an dan al-Hadits, diinterpretasikan oleh para Nabi dan sahabat.

5. Ajaran karakter dalam Islam meliputi segala segi hidup dan kehidupan manusia berdasarkan asas kebaikan dan bebas dari segala kejahatan. Islam tidak hanya mengajarkan tetapi menegakannya, dengan janji dan sangsi llahi yang maha adil. Tuntunan moral sesuai dengan bisikan hati nurani, yang menurut kodratnya cenderung kepada kebaikan dan benci pada keburukan.

Dari pemaparan di atas, menurut penulis bahwa pandangan Islam tentang hakikat pembentukan karakter anak bersifat mendalam dan menyeluruh, tidak terikat pada pada suatu pandangan tertentu dan tidak bertentangan dengan teori atau filsafat pendidikan manapun. Dalam pembentukan karakter Islam memandang dengan arah pandang yang komprehensif, mencakup semua aspek positif perkembangan integral: intelektual, spiritual, fisik, dan aspekaspek perkembangan lainnya sehingga dapat dilakukan melalui komunikasi interpersonal dan keteladanan orangtua, namun tidak hanya terpusat pada satu metode atau sarana tertentu.

Dalam hasil temuan dan penelitan mengenai komunikasi interpersonal antara orangtua dan anak murid kelas IV Sekolah Dasar Islam Al-Achfas Dwi Matra, secara umum cukup baik dalam membentuk karakter anak, melihat dari hasil angket dengan indikator keterbukaan dalam berkomunikasi antara orangtua dan anak sangat baik, sang anak senang dan tidak takut untuk berkomunikasi karena adanya rasa keterbukaan. Kemudian rasa empati terdapat 
dalam komunikasi antara orangtua dan anak, Dengan adanya rasa empati maka akan menimbulkan rasa kepedulian, kasih sayang dan keinginan untuk menolong sesama, karena rasa empati inilah yang mendorong seseorang untuk melakukan hal baik sehingga tumbuh menjadi karakter (Sumartono, 2004: 120). Komunikasi juga diringi sikap positif antara orangtua dan anak, meskipun terdapat beberapa orangtua murid yang masih mengeluarkan kata dan perbuatan negatif. Sikap positif ini bisa menumbuhkan karakter yang lembut hatinya, sang anak mempunyai rasa kasih sayang terhadap adik, teman, dan lingkungannya (Ratna Megawangi, 2004: 89). Artinya apabila orangtua terbiasa memberikan respon yang negatif maka sang anak hatinya akan menjadi keras dan tidak mau berkomunikasi dengan orangtua, sehingga akan muncul kebiasaan berbohong. Rasulullah Saw berteman dengan anak-anak hampir di setiap kesempatan. Kadang-kadang menemani Ibnu 'Abbas berjalan, pada waktu lain menemani anak paman beliau, Ja'far, juga menemani Anas. Begitulah Rasulullah berteman dengan anak-anak tanpa canggung dan tidak merasa terhina (Aam Amiruddin, 2011: 18).

Pada penelitian ini, proses pembentukan karakter anak di rumah secara umum cukup baik, hal ini dapat dilihat dari jawaban responden (orangtua) terkait 9 pilar karakter mengenai bentuk keteladanan orangtua, seperti "Apakah anda selaku orangtua selalu mengajarkan Tuhan dekat dengan anak?", 3 orang menjawab selalu, 1 orang menjawab terkadang.Pada pertanyaan lainnya, dan pertanyaan "Apakah Anda selalu menekankan perintah agama (dalam hal ini adalah menjalankan sholat lima waktu)?" 2 orang menjawab tentu dan sisanya menyatakan hanya diserahkan kepada ibu. Begitu juga dengan butirbutir pertanyaan yang berkaitan dengan komunikasi interpersonal dengan nilai keterbukaan di rumah, empati, sikap mendukung, sikap positif, dan kesetaraan. Hampir seluruh responden menyatakan jawaban positif.

Orangtua BRW, adalah orangtua yang cukup berpendidikan. Ayahnya adalah seorang lulusan D-III Jurusan Komputer, berprofesi sebagai security, ibunya BRW adalah seorang ibu rumah tangga yang kesehariaanya mengurus anak dan keluarga. Dalam hal pola pendidikan anak, kedua orangtua BRW termasuk kompak. Dalam arti mereka sepakat untuk mendidik anak bersama-sama, saling mendukung antara ayah dan ibu, hal ini membuat orangtua BRW berkikap tegas, yang dihiasi dengan komunikasi dan pemberian contoh nyata adalah salah satu faktor yang membuat anak-anaknya sangat patuh kepadanya, dan tidak mengeluarkan kata-kata kasar. Dalam hal berkomunikasi dan memberikan keteladanan, yang dilakukan orangtua BRW terkait dengan hal ini adalah dengan membiasakan anak-anak sejak kecil melakukan ibadah-ibadah melalui contoh dari orangtua. Kedua orangtua BRW membiasakan diri untuk melakukan ibadah-ibadah bersama-sama dengan anak. Meski orangtua BRW pada dasarnya merasa tidak terlalu menguasai ilmu-ilmu agama, namun berkeyakinan, yang dibutuhkan anak-anak bukan hanya orangtua yang luas pengetahuan agamanya, tapi bagaimana orangtua juga turut terlibat secara aktif bersama-sama anak dalam melakukan ibadah-ibadah, meski terkadang mereka tidak dapat selalu menemani anakanaknya. 
Orangtua SAA, ayahnya Strata-1 dan ibunya Strata-2. Ayahnya bekerja di sebuah bank swasta, dan ibunya seorang guru. Dalam hal pemahaman agama orangtua SAA memakai metode komunikasi dua arah. Sehingga dengan demikian anak mengetahui mengapa agama memerintahkan atau melarang suatu perbuatan. Dalam hal pembentukan karaker, orangtua SAA berusaha memberikan keteladanan dengan pembiasaan, seperti aktivitas solat yang diusahakan dilakukan dengan berjamaah. Ketika ayahnya pergi ke masjid, ia selalu mengajak anaknya yang laki-laki.

Orangtua BP. Komunikasi orangtua dan anak berjalan cukup baik, hal ini karena adanya pembiasaan dan tidak bosannya sang ibu untuk membimbing dan menegur sang anak, orangtua BP bekerja sebagai pedagang. Mereka mempunyai dua orang anak yang keduanya perempuan. Sebagai seorang pedagang, terkadang pekerjaan sang ayah cukup padat. Dengan demikian, ketika anak-anak pulang sekolah, anak tidak menemui ayahnya di rumah, yang ada hanya seorang ibu. Dalam urusan disiplin kadang sang ayah lepas kendali dan memarahi BP apabila melakukan kesalahan, hal ini disadari oleh orangtua tetapi komunikasi antara orangtua dan anak tetap terjalin. Sang ayah berusaha untuk senantiasa menjalin kedekatan anak, misalnya dengan bercengkrama di rumah, kerja bakti, atau jalan-jalan ke toko buku, rumah makan, swalayan, dan silaturahmi ke sanak famili, adalah kegiatan yang cukup sering dilakukan.

Kedua orangtua RS termasuk orangtua yang sibuk. Ayahnya seorang karyawan pada sebuah perusahaan swasta. Ibunya seorang perawat. Kedua orangtua RS, memiliki sifat yang berbeda dalam mendidik anak. Ibunya tegas dan disiplin, tidak otoriter. Menurut ibu, ia berusaha membuka pintu berpikir, membangkitkan motivasi belajar, dan mendorong potensi anak-anaknya sesuai dengan rambu-rambu nilai-nilai religius Islam tanpa "men-drill" mereka. Sedangkan ayahnya yang selalu mengantar kesekolah lebih bersifat sabar dan telaten dalam membimbing anak-anak belajar di rumah, dan cenderung lebih demokratis dalam mendidik anak-anak.Dirumah RS ada seorang pembantu dan nenek dari pihak ibu tinggal bersama mereka, namun kedua orangtua RS selalu mengajarkan anak-anaknya untuk melakukan sendiri pekerjaan-pekerjaan ringan yang mereka dapat melakukannya, seperti mengambil makanan sendiri, mandi dan berpakaian sendiri. Ada beberapa hal pola asuh yang diterapkan orangtua RS dalam menanamkan sikap hormat dan santun ini, di antaranya adalah dengan memberikan keteladanan, yang dilakukan orangtua adalah membiasakan mengucapkan salam saat masuk rumah, hormat pada ibu/bapak/kakek/nenek, dan menghargai pembantu, anak-anak dibiasakan juga untuk meminta izin apabila meminjam barang adik atau kakaknya. Dalam hal keteladanan dan komuniskasi berjalan cukup baik, orangtua RS cukup sadar bahwa setiap anak mempunyai kelebihan dan kekurangan, oleh karena itu berusaha tidak pernah menjelek-jelekkan, mengejek atau menceritakan kejelekan anak di depan sang, juga tidak selalu membandingbandingkan anak dengan kakak atau adiknya, apalagi dengan anak orang lain.

Sebagai informan, sebagian besar anak merasa telah mampu melihat keteladanan afektif dan psikomotorik yang orangtua mereka 
tunjukkan, merasa terbuka dan dihargai, meskipun sebagian kecil mengakui bahwa kedekatan ibu mendominasi dibanding ayah anak dan seringkali sebelum melakukan kewajiban, ada omelan, seperti yang dikatakan BP. Namun dalam observasi, komunikasi dua arah yang terus dibangun orangtua, memberi ruang anak untuk dapat belajar memahami, sehingga keteladanandapat lebih mudah diaplikasikan anak.

\section{KESIMPULAN}

Berdasarkan uraian dan analisisi yang terdapat dari teori dan temuan penelitian tersebut dapat diberikan kesimpulan sebagai berikut:

1. Bahwa pembentukan karakter anak SDI AIAchfas Dwi Matra Jakarta Selatan melalui komunikasi interpersonal orangtua cukup baik, karena adanya kelekatan jiwa yang membuat komunikasi antara orangtua dan anak yang bukan bersifat indoktrinasi atau propaganda, akan tetapi, suatu proses yang bersifat mendidik, komunikatif dan membangun (konstruktif).

2. Orangtua yang peluang kepada anak untuk berkomunikasi dan menciptakan hubungan mesra membuat anak lebih peduli terhadap harapan orangtua.

3. Sebelum berpikir untuk membentuk karakter anak, orangtua hendaknya membentuk karakter dalam dirinya Pembentukan karakter anak dalam pandangan Islam mencakup semua aspek positif perkembangan integral: intelektual, spiritual, fisik, dan lainnya sehingga perlu dilakukan bertahap dan integral.

\section{DAFTAR PUSTAKA}

Ahmad Ghulusy (1987), Ahmad, ad-Da'watul Islamiyah, Kairo: Darul Kutub

Akbar Hawadi, Reni (2004), Akselerasi: A-Z Informasi Program Percepatan Belajar dan Anak Berbakat Intelektual, Jakarta: PT. Gramedia,

Al-Ghazali (tt), al-Maqshad al-Asnā Syarh Asma Allah al-Husna, Mesir: Maktabah al-Jundi

Amiruddin, Aam (2011), Sudahkah Ku Didik Anakku dengan Benar?Jakarta: Gramedia Pustaka Utama

Anis Matta, M. (2002), Membentuk Karakter Cara Islam, Jakarta: Al-I'tishom Cahaya Umat

A. Nasir, Sahilun\&Anshari, Hafi (1989), PokokPokokPendidikan Agama Islam di PerguruanTinggi, Surabaya: Al-lkhlas

Baidhawy, Zakiyuddin (2007), Pendidikan Agama Berwawasan Multikultural, Jakarta: Erlangga

Chatib, Munif (2009), Sekolahnya Manusia: Sekolah Berbasis Multiple Intelligences di Indonesia, Bandung: Kaifa, Cet. IV

Gichara, Jenny (2006), Mengatasi Perilaku Buruk Anak, Jakarta: Kawan Pustaka

Gordon, Thomas (1989), Menjadi Orangtua Efektif, terjemahan Tim Psikolog Klinis, Jakarta: Gramedia

Hajr al-Asqolani, Ibnu (1958), Fath al-Bari Syarah al-Bukhari, Beirut: Daar al-Ma'rifah, Jld X

Koesoema Albertus, Doni (2010), Pendidikan Karakter: Strategi Mendidik Anak di Zaman Global, Jakarta: Grasindo

Megawangi, Ratna (2008), Character Parenting Space: Menjadi Orangtua Cerdas untuk Membangun Karakter Anak, Bandung: Read!

(2004), Pendidikan Karakter Solusi yang Tepat untuk Membangun Bangsa, Jakarta: BP Migas dan Star Energy 
Moleong, Lexy J (2010), Metodologi Penelitian Kualitatif, Jakarta: Remaja Rosdakarya, Cet. XXVII

Muis, Abdul (2001), Komunikasi Islam, Bandung:Remaja Rosadakarya

Mulyana, Dedy (2000), Ilmu Komunikasi, Bandung:Remaja Rosadakarya

Mulyana, Deddy, dan Ibrahim, Idi Subandy (1997), Bercinta Dengan Televisi llusi dan Imaji Sebuah Kotak Ajaib, Bandung: Remaja Rosdakarya

Nata, Abuddin (2007), Manajemen Pendidikan: Mengatasi Kelemahan Pendidikan Islam Indonesia, Jakarta: Kencana

Samani, Muchlas, dan Hariyanto (2012), Konsep dan Model Pendidikan Karakter, Bandung: Remaja Rosdakarya, Cet II

Semma, Mansyur (2008), Negara dan Korupsi: Pemikiran Mochtar Lubis atas Negara, Manusia Indonesia dan Perilaku Politik, Jakarta: Yayasan Obor Indonesia

Sugiyono (2006) Metode Penelitian Pendidikan: Pendekatan Kuantitatif, Kualitatif dan R\&D, Bandung: Alfabeta

Sujanto, Agus (2006), Psikologi Kepribadian, Jakarta: Bumi Aksara, Cet IIV

Sumartono (2004)Komunikasi Kasih Sayang, Jakarta: Elex Media Komputindo

Supratiknya, A (1995)Komunikasi Antar Pribadi Tinjauan Psikologis, Yogyakarta: Kanisius 